\title{
AZ ÁTALAKULÓ TERROIR - EGY TERMÉSZETFÖLDRAJZI FOGALOM TÁRSADALOMFÖLDRAJZI ÁTÉRTÉKELÉSE
}

\author{
KISMARJAI BALÁZS \\ THE TRANSFORMING TERROIR: SOCIO-GEOGRAPHICAL \\ EVALUATION OF A PHYSICAL GEOGRAPHICAL CONCEPT
}

\begin{abstract}
As a winemaking concept, terroir has had a "lightning career" in recent decades. Initially used by a narrow professional class, the term has now become more popular. It is unavoidable for the wine economy, the market and consumers. The fundamental study of terroir has been carried out primarily within the framework of physical geography, and only in the last two decades has social geography and other social sciences played a growing role in this research. The expansion of the wine market, the emergence of foreign terroir wines, and the European Union's regulation of protection of origin, which is also based on terroir, have made the concept more well-known in Hungary as well. At the same time, the Hungarian perception, and even the vast majority of domestic terroir studies, still follow the physical geographical approach. I consider it very important that the latest social science studies also have a place in terroir research in Hungary, because these are absolutely necessary for understanding and applying the concept in Hungarian conditions. The present study attempts to begin to fill this gap.
\end{abstract}

Keywords: terroir, definition of terroir, protection of origin

\section{Bevezetés}

A terroir, mint borászati fogalom, az elmúlt évtizedekben „villámkarriert” futott be. A kezdetben szűk szakmai réteg által használt kifejezés mára népszerű lett. Megkerülhetetlen mind a borgazdaság, mind az értékesítő és fogyasztó szempontjából is. A terroir alapvető vizsgálata elsősorban a természetföldrajz keretein belül történt, és csak az elmúlt két évtized hozta magával a társadalomföldrajz és más társadalomtudományok erôsödő szerepét. A borászati piac szélesedése, a külföldi terroir-borok megjelenése, valamint az Európai Unió eredetvédelmi szabályozása, ami szintén a terroir-on alapul, Magyarországon is szélesebb körben tette ismertté a fogalmat. Ugyanakkor a hazai felfogás, sőt a hazai terroir-vizsgálatok is nagy többségükben még a természetföldrajzi megközelítésnél tartanak. Nagyon fontosnak tartom, hogy a legújabb társadalomtudományi vizsgálatok is helyet kapjanak a magyarországi terroir-kutatásokban, hiszen ezek feltétlenül szükségesek a fogalom megértéséhez és alkalmazásához a hazai viszonyok között. Jelen tanulmány ezt a hiányt kísérli meg betölteni.

\section{Vidék, táj, terroir}

A földrajztudomány egyik legfontosabb kérdésköre a vidék és a táj fogalmának tisztázása. Ahhoz, hogy az elmúlt évtizedekben világhódító útra lépett terroir-t értelmezni tudjuk, egy-két gondolat erejéig érdemes kitérni a vidék és a táj fogalmának meghatározására is. A vidék kifejezés értelmezése feletti vita máig nem csitult el, a kérdéssel foglalkozó kutatók különböző módszereket használva próbálják a fogalmat lehatárolni, értelmezni. Ezekhez kapcsolódik a köznapi értelmezés, ami erősen pejoratív tartalommal 
ruházza fel ezt a fogalmat. A „magyar vidék” esetében egyéb tényezők is befolyásolják a meghatározást, hiszen pl. a népsûrűség alapján hazánk csaknem egész területe a vidék kategóriába esne (ILLÉs I. 2008). Ráadásul a vidék mára teljesen átalakult, a városi életmód, gyakran a kiköltöző városi népesség már meghatározóbb a vidéki térségekben (SzABÓ Sz. 2011).

A Nemzeti Agrárprogram (1997) szerint a vidék a mezőgazdasági tevékenység területe, ahol a zöldfelület dominál, alacsony a népsűrűség és a beépítettség. A Nemzeti Vidékstratégia 2012-2020 a vidék fejlesztését már többféle indokkal támasztja alá. Meg kell őrizni a természeti erőforrásokat, a mezőgazdaság fejlesztésével a fenntartható gazdálkodás a vidék fejlődéséhez fog vezetni. Ez alapvetóen szükséges a biztonságos élelmiszerellátáshoz - még ha a bor nem is tartozik az alapvetó élelmiszerek közé, a szőlőre alapozott gazdasági szektor borvidékeink településein közel 100\%-ban meghatározó. Ehhez kulcsfontosságú a táj megőrzése, fenntartása, a talaj védelme, a helyi közösségek és kultúra megőrzése.

Ezek alapján a vidék tehát rendelkezik határozott ismertetőjegyekkel, azaz tulajdonképpen egy földrajzi régió, a táj pedig nem más, mint ennek speciális megjelenése. Kutatása az ezredfordulótól kezdve - a globális problémák természet- és társadalomföldrajzi kivetülésének köszönhetően - ismét meggyorsult (KARÁCSONYI D. 2010). Mások táji öntudatról beszélnek, a társadalom viszonyáról a lakóhely térbeli környezetéhez, a társadalom átalakító szerepérôl, ami a területhasználatban is megmutatkozik (CSATÁRI B. 2006). ENYEDI Gy. (1965) a mezőgazdasági múvelés hatására kialakult agrártájról ír, ahol a természeti és társadalmi tényezók együtt alakítják ki a jellegzetességeket.

A terroir francia eredetű szó, szó szerinti jelentése „,föld”, „talaj”. A kifejezés a XII. század végén jelent meg először írott dokumentumokban tioroer (1198), terroit (1202), tieroir (1212) formában (LETURCQ, S. 2020). Fontos hangsúlyozni, hogy kezdetben egyáltalán nem bírt olyan jelentéssel, mint manapság, csupán lehatárolt mezőgazdasági földterületet jelentett (vö. ENYEDI GY. 1965; DÉKÁNY T. 2017). A másik fontos különbség, hogy egészen a XVIII-XIX. századig a mai értelemben vett terroir hatást a borra (az egyedi termőhely adta szín, illat, íz) nem tekintették pozitívnak, sőt kifejezetten rossz bornak tartották azokat, amelyekben ezek megjelentek (LETURCQ, S. 2020), s csupán a XIX. századtól vált a terroir-ból pozitív koncepció.

A XIX. században már olyan vidéki területnek tartották, amely képes befolyásolni az ott lakók életét (DELOIRE, A. et al. 2008). A francia szőlőtermesztésben lezajlott sajátos fejlődés magával hozta, hogy egy-egy területen kevés, de nagyon jellegzetes szőlőfajta maradjon termelésben. A termelők számára csak a termőterület adhatott lehetőséget a különbségek megjelenítésére. A kitettség, az eltérő anyakőzet, a talaj ásványianyag-tartalma felismerhető különbséget biztosított a boroknak. A francia eredetvédelmi rendszer ki is használja ezt. A legszebb példa erre Burgundia, ahol az anyakőzet típusa és a lejtő határozza meg a dúló vagy parcella besorolását (1. ábra).

A legjobb minőséget adó parcellákat a lejtő közepén (,veséjén”) találjuk. A középsőjurából származó callovi mészkövön kiváló összetételú talajréteg alakult ki, nem véletlenül itt hozták létre a legmagasabb kategóriájú, ún. „grand cru” zónát. A domboldal felső része meredekebb, ahonnan a talaj könnyen lepusztul, így a felsőjura oxfordi márgán már csak az eggyel alacsonyabb kategóriájú ,,premier cru” területek jöttek létre. Végül a völgy alján, a domboldalról lemosódott üledékek mellé a Saône mellékvizeinek alluviális hordaléka is csatlakozik, így a márgás-mészköves anyakőzeten már csak a leggyengébb minőséget adó települési és regionális besorolású bortermő területek helyezkednek el. Emellett a lejtő részeinek kitettsége, így mezoklimatikus jellemzői is mások (HAYNES, S. J. 1999). 


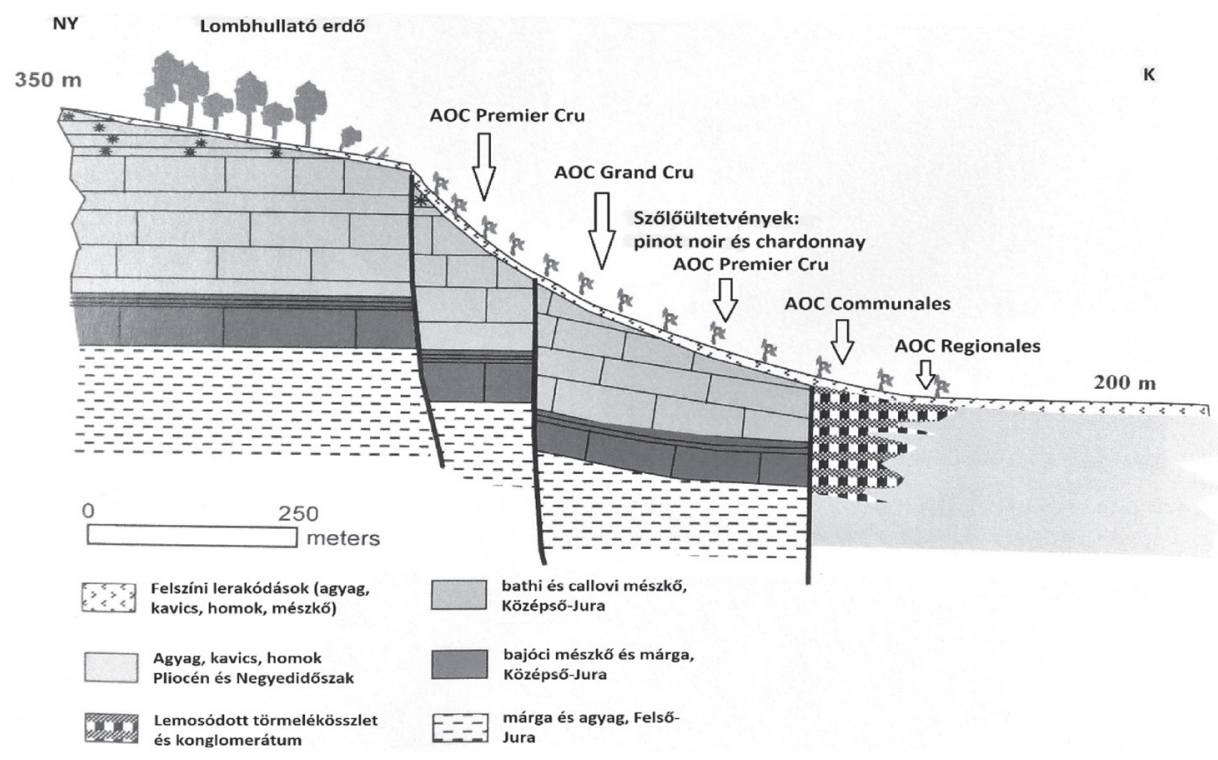

1. ábra A Côte d’Or szerkezeti ábrája és a borvidéki besorolás kategóriái Forrás: LemAiR, D.-KASSERMAN, D. (2012. 70.) alapján saját szerkesztés Figure 1 Cross section of the Côte d'Or and categories of AOC Source: after LemaiR, D.-KASSERMAN, D. (2012. 70.)

\section{A terroir táguló értelmezése}

Az így létrejött besorolási szisztéma foglalkoztatja az ottani geográfusokat is, főleg a terroir lehatárolásának kérdésköre kapcsán. Szerintük a terroir nem csak a mezőgazdasági tevékenység kerete, hanem a szocio-térbeli szerveződés egysége is, amely képes leírni egyes földrajzi területek agrárkultúráját (COCHET, H. 2012).

A francia terroir-kutatások alapvetése, hogy a termelésben részt vevő gazdaságok, vállalkozások mindig egy meghatározott területen gyökereznek, az adott tájegység részei. Emiatt a terroir elemzése elengedhetetlen az adott régió és annak termelési rendszere megértéséhez (CoCHET, H. et al. 2006). E vizsgálatoknak ki kell térniük az adott táj értékelésére, mint egy sokváltozós, komplex termelési rendszerre; a terület történelmi folyamataira, mert ezek nélkül értelmezhetetlen az egész szisztéma; majd végül be kell mutatni az összefüggéseket a konkrét terület és a termelési rendszer között.

Az elkezdődött vizsgálatok köré hamar egy szélesebb kutatói bázis gyúlt össze, kialakult az egyesek által már ,,terroir-iskolának” nevezett csoport (COCHET, H. 2012). Nekik megkerülhetetlen szerepük volt és van a vidéki térségek agrárrendszerének elemzésében. Az irányzat szerint az agrártáj elsődlegesen társadalmi folyamatok révén, hosszú idő alatt létrejövő kategória, ahol egy meghatározott társadalmi struktúra és a megmúvelt földterület között történelmi kapcsolatrendszer alakul ki. COCHET mindezt hat pontban foglalja össze: (1) az agrárökoszisztéma jellemzői; (2) a területen gazdálkodó technológiai öröksége; (3) az emberi tevékenység által átalakított környezet; (4) az így keletkezó agrártáj; (5) a környezeti feltételektől függő agrár-ökoszisztémák közötti kapcsolatok; (6) a talajt megújító folyamatok (CoCHET, H. 2012. 130.). A felsorolás azonban hiányos, nem tartalmazza a véleményem szerint szintén erósen meghatározó társadalmi-kereskedelmi kapcsolatokat, az általuk befolyásolt tényezőket. 
CocheT-val egyetértve PRÉvost és munkatársai is a terroir földrajzi kutatásakor a természeti tényezók mellett az emberi örökség, azaz a társadalmi szempont figyelembevételét tartják meghatározónak. A terroir ugyanis - írják - dinamikus fejlődéssel, múlttal, jelennel és jövővel rendelkező innovatív tér, ahol mindez a természeti környezet és a társadalmi tényezők kölcsönhatása révén alakul ki (Prévost, P. et al. 2014). A terroir szúkebb, természeti megközelítését ők a szőlő- és borkultúra angolszász (azaz az USA) túlsúlyú értelmezésének tudják be. Hasonlóképp vélekedik PITTE, J-R. (1999), aki a talaj és a természeti tényezők túlértékelését egy elkészült képzőmúvészeti alkotás anyagával állítja párhuzamba - ott is a múvész ,keze” alkot, nem pedig a márvány vagy a festóvászon. A terroir esetében is sokkal fontosabb szerepe van a generációk gyakran évezredes tapasztalatának, a know-how fejlődésének, ami az adott területen összekapcsolja a természetet a társadalommal. A terroir kialakulásában a történelmi és térbeli diffúziót, a folyamatos technológiai innovációt tartja fontosnak MABY, J. (2002), aki a „terroir-iskolához” hasonlóan a társadalomra koncentrál. A termeló életmódja, társadalmi háttere, kultúrája, hagyományai, a technológiai összetevők sokkal jobban meghatározzák a terroir-t, mint a természeti tényezők. A terroir ugyanis klimatikusan nem biztos, hogy homogén, de társadalmilag igen, közös történelemmel, a helyi gyakorlatok folytonosságával (BARJOLLE, D. et al. 1998).

Náluk is tovább lép a szintén francia Demossier, M. (2011), aki a táj- és terroir-kutatásokban hiányolja a szociál-antropológia és egyéb társadalomtudományok részvételét, pedig azok szerinte kulcsszerepet játszanak a definiálásban, hiszen a generációs tudástól kezdve az éppen használt technológiáig a teljes humán faktor részt vesz a rendszer létrehozásában. Véleménye szerint a terroir „a helyi erók és a globalizáció összetett kölcsönhatásának paradoxona", azaz a XXI. századi terroir válasz a globalizált mezőgazdasági termelésre valamiféle egyedi termék előállításával. Szerinte a terroir ilyen szintú létrejöttében nagy szerepe volt a helyi eliteknek, amelyek ezen keresztül tudták védeni, megtartani társadalmi-gazdasági helyzetüket. Ezért aztán a terroir definiálásában az alulról való szerveződés játszott szerepet, a helyi tulajdonosoknak lehetőségük volt részt venni a paraméterek kialakításában.

A terroir az elmúlt évtizedekben befutott „karrier” miatt láthatóan ma már a borászatban, a borászati földrajzban rengeteg jelentéssel, jelentésárnyalattal bíró fogalommá vált. Mindezt annak az egyértelmú ténynek köszönheti, hogy a palackba kerülő bor íz- és illatbeli karakterét a természeti és társadalmi környezetből kapja, ahol a szőlő nő, illetve a bor készül. Azaz mindebbe beletartozik a talaj, a domborzat, az éghajlat, valamint a borászati technológia és kulturális környezet is (2.ábra) - tehát nehezen megfogható fogalomról beszélünk (WiLSON, J. E. 2001). Nem véletlen, hogy a tudományos és a köznyelvi meghatározás között feszültség, gyakran ellentét van.

Napjainkban a szőlészeti és borászati munkák erősen specializálódtak. A technológiai döntések alapvetóen képesek változtatni a bor minőségén, hiszen a hordósság, a tannin teljesen átalakítja a bor ízét, a seprős érlelés növeli a testességet. A természeti adottságok és a társadalmi know-how együttmúködését, együtt változását nevezik a terroir esetében „koevolúciónak” (PoLGE, M. 2003). E technológiai/társadalmi és természeti kapcsolat miatt a terroir egy specifikus terület, speciális termelési folyamattal, amely garantált minőséget ad. Eredetjelző, aminek feltüntetésével a fogyasztó elvárja a magasabb minőséget. És mivel ilyen termelői-vásárlói kapcsolatban a két fél közötti kölcsönös bizalom az alap, létrejön a „társadalmi terroir”, ami a kommunikáción alapul (SPIELMANN, N.-GÉlinAS-CheBAT, C. 2012). A terroir kommunikációja e szerzők szerint kettős: fogyasztói és termelői, amely mindkét fél részéról felöleli a természeti környezetet, a történelmi hagyományokat és a helyi tudást (3. ábra). 


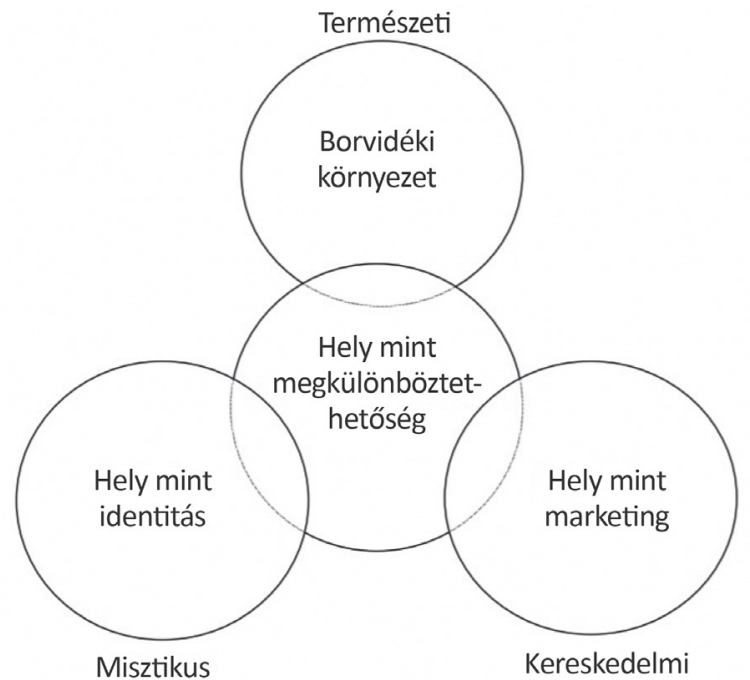

2. ábra A terroir-alkotó koncepciók. CHARTERS, S. (2010) alapján saját szerkesztés Figure 2 The conceptions of the terroir. Source: after CHARTERS, S. (2010)

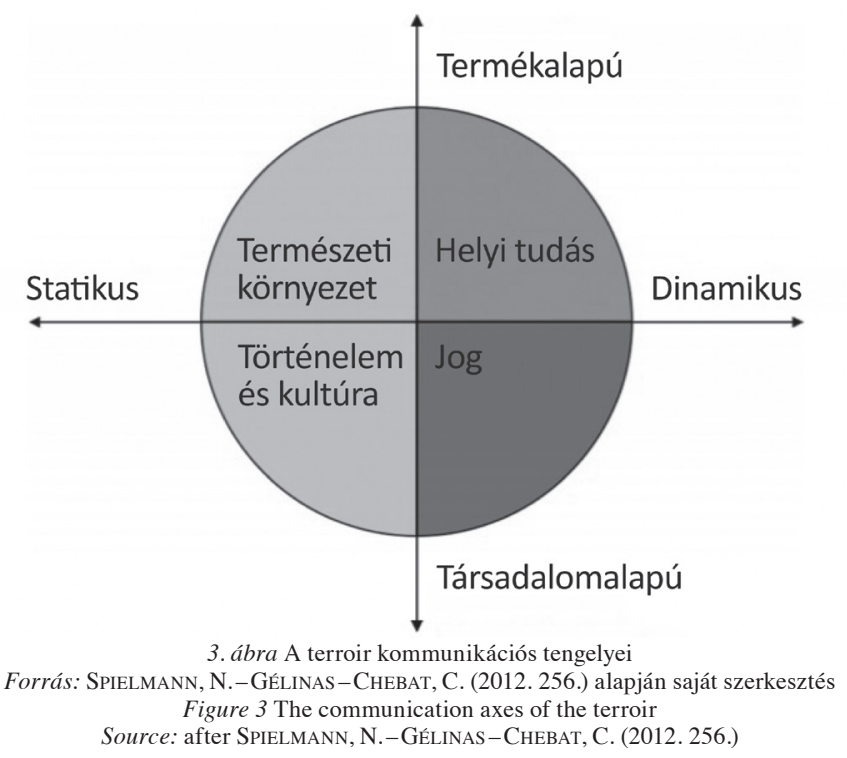

Hasonló megfontolásokból tekintik a terroir-t interaktív ökoszisztémának, azaz a terroir mint adott terület, az éghajlat, a talaj, a szőlő, valamint az elkészített bor kapcsolatát a társadalmi-kulturális tényezőkkel (van LeEuwen, C.-SEguin, G. 2006). Úgy vélik, hogy mivel a Föld egymástól teljesen eltérő természeti adottságú területein készítenek kiemelkedő minőségú borokat, lehetetlen meghatározni „A terroir” ideális elemeit. Ezeket természetesen figyelembe kell venni, de a humán faktor szerepe megkerülhetetlen. Így lesz a szőlőből „,terroir bor”, ami egy meghatározott területen elóállított, ezért tovább nem növelhetô mennyiségú, emiatt magas áron eladható nedú. 
Az interaktivitás és a változás más kutatóknál is megjelenik, mint fő tényező. A terroir körülhatárolt földrajzi terében ugyanis az emberi közösség „épít” és „alkot”, felhasználva a kollektív termelési ismereteket, a társadalmi-technikai folyamatokat. Ezek állandó módosulása adja a terroir-t, biztosítva a termék eredetiségét (CASABIANCA, F.-GIRAUD, G. 2011).

Megállapíthatjuk, hogy a terroir, mint egyediséget jelző területi fogalom, hazájában - Franciaországban - már meghaladja azt a szúkebb értelmezést, amely a természeti tényezőket és hatásokat tartja elsődlegesnek. A szerző véleménye szerint ez az irány az előremutató, ami magával fogja húzni, át fogja alakítani az Újvilág terroir-ra vonatkozó elképzelését is.

\section{Az Óvilág-Újvilág ellentét}

A XX. század második felétől dominánssá váló francia terroir elképzeléssel szemben szinte azonnal megjelent a feltörekvő újvilági bortermelő országokhoz köthető álláspont, miszerint a terroir nem más, mint válasz az újvilági termelők sikerére. A borfogyasztás piacán ugyanis ekkorra megkerülhetetlenné vált az Egyesült Államokon belüli eladás. A dinamikusan fejlődő piac méreténél fogva elsődleges célpontjává vált az európai termelőknek is. A globális piac létrejötte pedig magával hozta a borok uniformizálódását, a „világízlés” kialakulását.

A kapcsolatot a terroir és a világpiac között legjobban az ún. „,terroir-háromszöggel” lehet ábrázolni (4.ábra). Az alapot, a szigorúan vett terroir-t, a parcellák jelentik, amelyeket a különböző dúlókben találunk. Ezek azok a területek, ahol akár egymástól teljesen eltérô ásványokat, összetevőket találhatunk, lehetőséget adva a borásznak, hogy a technológia

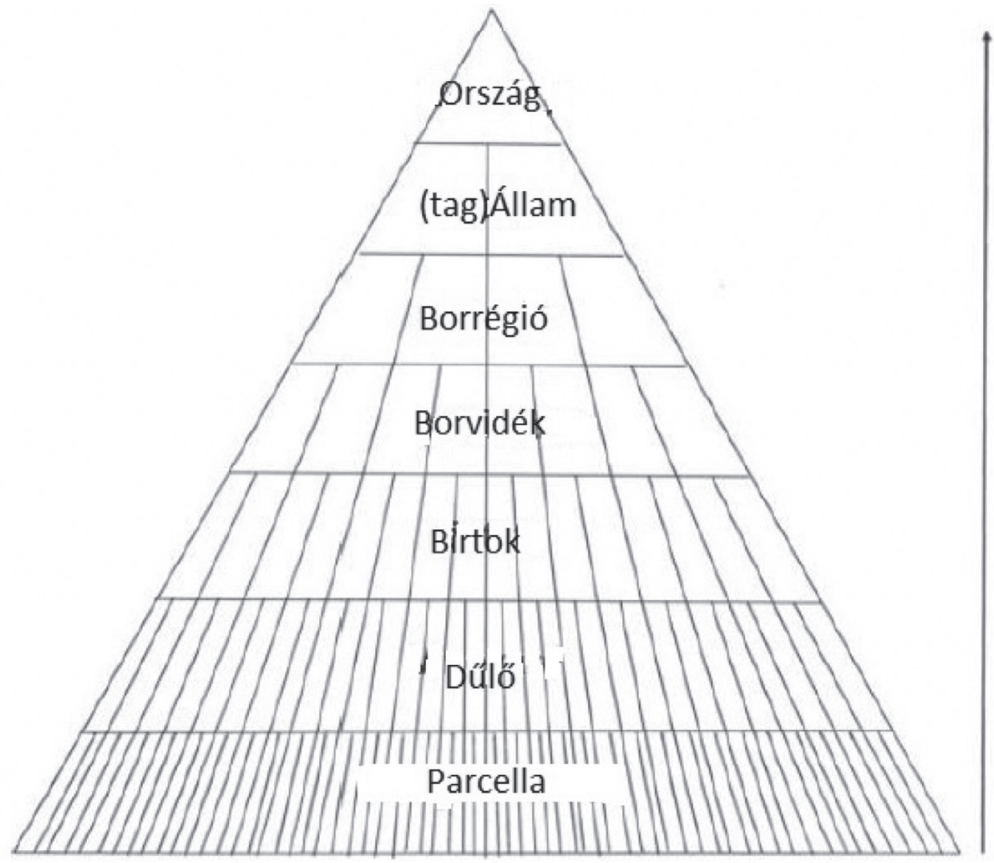

\section{Világízlés \\ Globalizáció}

\section{Terroir Egyediség}

4. ábra A terroir-háromszög. Forrás: DougherTy, P. H. (2012. 27.) alapján saját szerkesztés Figure 4 The terroir triangle. Source: after DougherTy, P. H. (2012. 27.) 
bevonásával különböző borokat tudjon készíteni. Kétségtelenül ezek a világ legdrágább borai, köszönhetôen annak, hogy kiváló természetföldrajzi jelleget tovább erôsítik a társadalmi-kulturális tényezők. A háromszög csúcsát az országok jelentik, amelyek azonban már a kornak megfelelő borízlést képviselik, természetesen az országnak megfelelő brandre alapozva. Európában a „tagállam” szintnek nem különösebben van jelentősége, ez csak a hatalmas területekkel rendelkező újvilági országok, például az USÁ vagy Ausztrália esetében értelmezhető. Pontosan azokban, amelyek nem hisznek a terroir-ban.

Az 1980-as években hangos volt a borászati sajtó az utóbb „nagy terroir vitának” nevezett cikksorozattól, ami a Decanter magazin hasábjain kapott helyet. A vita elindítója JeKel, B. (1982, 1983a, b) és Prats, B. (1983) volt. A kaliforniai borász, JeKEL Montereyben alapította meg saját pincészetét, PRATS pedig az egyik legnagyobb elismertségú borvidéken, a bordeaux-i Saint-Estèphe területéhez tartozó híres Château Cos D'Estournel igazgatójaként dolgozott.

Cikkeiben JEKEL arról írt, hogy a talaj hatása elhanyagolható minőségi változást okoz borokban. Azt ugyan nem jelentette ki, hogy semmilyen szerepe nincs a talajnak, de hatását az ásványosságra szúkítette. Vitába szállva vele, PRATs kiállt a talaj adta karakter mellett. Ugyanakkor ő nem csupán a szúken vett értelmú talajról, hanem a terroir-ról beszélt: mindarról az összességről, a hagyományról, a tapasztalatról, amely a nagy francia borokat adja.

JEKEL és PRATS vitája azóta tovább folytatódott, újabb és újabb szereplők léptek be a ma már inkább Óvilág-Újvilág vitába. Sajnos a téma ezáltal erodálódott is; sokan sokszor használják rosszul a különböző kifejezéseket (talaj-kőzet; mikroklíma-mezoklíma), emiatt az egykor szakmai vita mára populáris témává változott (UNwIN, T. 2012).

Az 1960-as évektôl felfutó újvilági bortermelés sokáig lenézett és megtúrt szerepben létezett. Ezért érte a szakértőket meglepetésként, a francia borászokat pedig megdöbbentette, amikor egy 1976-ban rendezett Kalifornia-Franciaország borversenyen minden kategóriában az amerikai borok győztek. A szakmai reakciók mindezt a terroir kritikájaként fogták fel - „megsemmisült a terroir” - és azonnal megkezdődött a válasz keresése.

A legfontosabb tanulság, hogy a borászat fejlődése az Újvilágban teljesen más alapokról indult, mint Európában. Igaz, a spanyol gyarmatosítók már igen hamar átvitték a szőlőt az amerikai kontinensre, az igazi ugrás mégis a XIX. században következett be. Azonban az akkori viszonyoknak megfelelően, a termelők nem azt a helyet keresték, ahol az optimális feltételeknek köszönhetôen a legjobb minőségú bort lehet megtermelni, hanem azokat a területeket, ahol a szőlő a legjobban nőtt és termett, hogy a megfelelő mennyiséget tudják elóállítani. Ennek megfelelően a klíma volt a fő szempont, nem pedig a talaj; ez pedig a jó technológia alkalmazásával jó borok előállításához vezetett. A másik szempont, hogy az újvilági borokat ma is inkább folyóborként adják el, ellentétben az óvilágiakkal. A folyóborok nagy mennyisége miatt pedig a termelők a lehető legjobb ár-érték arányra törekednek, ami a konformizálódást és a terroir háttérbeszorulását okozza (UNWIN, T. 2012).

A hatalmas újvilági borvidékeken tehát sokkal kevésbé fontos a terroir, mint a kisebb területű, ezért a kitűnésre, a különlegességre törekvő európaiakon. Mindezt az újvilági terroir-definíción is megfigyelhetjük. Az óvilági terroir homogén terület, ahol a domináns térbeli jellemzők a társadalmi-történelmi szempontokkal együtt érvényesülnek a szőlőtermesztésben és a borkészítésben, generációkon keresztül öröklődő tudásként, míg az újvilági terroir idő- és térbeli egységként írható le, ahol sokkal nagyobb jelentôsége van a talajnak, a tájnak, valamint az éghajlatnak, szemben a társadalmi, történelmi és kulturális affinitással (SHANMUGANATHAN, S. 2010).

Mégis, több olyan tendenciát is megfigyelhetünk, amelyek azt mutatják, hogy az Újvilág egyes borvidékein is megindult a terroirosodás, azaz a termőterületeken belüli részletesebb klasszifikáció. Ezek azonban elsősorban még a természeti feltételek alaposabb vizsgálatán 
és az így megállapított különbségeken alapulnak. Így modellezték az oregoni Umpquavölgy természeti környezetét, és csoportosították a szőlőtermő területeket (JONES, G. V. et al. 2004), vizsgálták az új-zélandi borvidékeket éghajlat, domborzat és fajtaszerkezet alapján, ami a szerzők szerint a borvidéki terroir kialakításában elsődleges fontosságú (IMRE, S. P.-MAuk, J. L. 2009; Shanmuganathan, S. 2010). Egy másik kutatásban szintén a természeti adottságok hatásait keresték a szőlöültetvények árában a szintén oregoni Villamette-völgy borvidékén. A kutatás eredménye, hogy a legdrágább parcellák, illetve borok azokról a helyekról jönnek, amelyek már megjelenítik a borvidéken belüli („,subAVA" - American Viticultural Areas) elhelyezkedésüket (CROSS, R. et al. 2011).

Ezek a példák is mutatják, hogy a terroir elsődlegességét el nem fogadó újvilági álláspontot lassan felülírja az egyediséget előtérbe helyező társadalmi elvárás. A fogyasztók - azaz a piac - szerepe: amint felismeri egy bortermő terület különlegességét (a tanulmányban ez Új-Zéland és az USA), abban a pillanatban elindítja a terroir létrejöttének folyamatát (DELOIRE, A. et al. 2008). Sőt, egyes újvilági területek már most rendelkeznek olyan egyedi technológiai tudással, ami megerősíti a terroir táguló, a szúkebb természeti tényezők elsődlegességét meghaladó értelmezését.

\section{A terroir definiálása}

Mint azt a fenti példákon keresztül bemutattam, a terroir fogalom meghatározását több évtizede viták övezik. Az ellentétek feloldását segítik az 1996 óta megtartott terroir-konferenciák. Az angolszász megközelítés még mindig elsősorban a fizikai környezet vizsgálatát helyezi előtérbe, szemben a francia állásponttal. Az elmúlt évek kutatásai és az évtizedek óta folyó terroir-vita során többféle új definíció keletkezett. Ezek azonban szükségszerūen leegyszerúsítések, sok esetben csak a terroir egyes elemeit tartalmazzák. JoHnson, H. és RoBinson, J. (2012) neves borszakértők szerint a terroir nem más, mint a dúló és a borvidék természeti karakterének kifejezése. Nagyon érdekes - egyszersmind furcsa -, hogy egyikük se veszi figyelembe: a bor sokkal komplexebb áru annál, hogy minőségét csak a klíma és a talaj határozza meg.

Hozzájuk csatlakozik SOMMERs, B. J. (2008), aki ugyan geográfus, mégsem tud elszakadni a terroir pusztán természetföldrajzi megközelítésétől. Nála az „elméleti terroir” - a talaj, a kőzet, az éghajlat, az időjárás és a domborzat - mellett feltűnik a „gyakorlati terroir” kifejezése. Szerinte ez utóbbi nagyban alapoz a talajra, hiszen az a leginkább meghatározó tényező. Hivatkozik az anyakőzetre, amely az aprózódással és az erózióval a lejtőszögnek megfelelően befolyásolja az adott szőlőterület termőképességét.

A Sorbonne egykori geográfus elnöke, PITTE, J-R. (2008) szerint a fenti nézőpont csupán a természeti környezet csábítása és illúziója,hiszen a borvidékeken - sok esetben ezer évre visszanyúlóan - generációk gazdálkodnak, s tevékenységükkel teljesen átformálták a területet, megváltoztatták a talajt, ezért azt szinte nem is tekinthetjük „,természetesnek”. Ugyanúgy nem esik szó a technológiáról, noha annak karaktere képes felülírni a „természeti terroir-t”.

Tanulmányában TRUBEK, A. B. (2008. 18.) a francia ételek és italok egyedi ízét emeli ki, emiatt ő a terroir-t külön, alapvetô fontosságú kategóriának tekinti, amely megmagyarázza a kapcsolatot a föld és az ember között, és ,időtlen, akár a Föld maga”. AssELIN, CH. és munkatársai megfogalmazásában a terroir olyan körülhatárolt hely, ahol az emberek generációi megkülönböztetett életmódot folytatva egyedi, különleges termékeket hoztak létre (idézi Unwin, T. 2012. 39.).

A terroir-t elutasító egyesült államokbeli álláspontot képviselő, és szintén master of wine címmel bíró John Atkinson szerint manapság a terroir egyfajta hitté vált: valami, amit 
inkább hinni kell, mint bizonyítani (ATKInson, J. 2011). Mások szerint a terroir misztikus kifejezéssé vált, ami nem tesz jót a fogalommal kapcsolatos vitának (DELOIRE, A. et al. 2008).

A terroir definiálásával több nemzetközi szervezet is megpróbálkozott. Egyikük, az UNESCO konferenciát is szervezett a kérdés megtárgyalására. Az elfogadott definíció olyan földrajzi területröl szól, ahol az emberi közösség a történelem folyamán, a környezettel kölcsönhatásban, egyedi kulturális jellegzetességeket, ismereteket és gyakorlatokat alakított ki. Ez a felhalmozott tudás bemutatja az adott terület eredeti termékeit és szokásait és az ott élő embereket (UNESCO 2005).

A legautentikusabbnak tekinthető forrás, az OIV (Nemzetközi Szőlészeti és Borászati Szervezet) is megfogalmazta saját maga definícióját a terroir-ról. A 2010-ben Tbilisziben elfogadott meghatározás szerint „a szólészeti-borászati terroir fogalma olyan területre utal, amelyen kollektív tudás halmozódik fel a meghatározott fizikai és biológiai környezet és az alkalmazott szólészeti és borászati gyakorlat egymásra hatásával, ezáltal egyedi karaktert ad az adott területról származó terméknek. A terroir magában foglalja a jellegzetes talajtani, domborzati, klimatikus és táji karaktert, valamint a biodiverzitás sajátosságait" (OIV 2010). Az OIV meghatározásánál azonban tisztában kell lenni azzal, hogy a nemzetközi szervezet a tagországok lobbierejének megfelelően múködik, azaz figyelembe kell venni az újvilági bortermelő országok véleményét, valamint nagy súllyal esik latba az USA, mint a világ legnagyobb borfogyasztó piacának álláspontja. A definíció tehát szükségszerúen kompromisszum, ami emiatt nem adhat mélyebb értelmezést.

\section{A terroir-felfogás Magyarországon}

A magyarországi terroir-felfogás némileg különbözik a nemzetközitől. A hazai szőlő-bor ágazat fejlődése során - Tokaj kivételével - sehol sem alakultak ki olyan feltételek, amelyek lehetővé tették volna a francia típusú terroir-nak akárcsak halvány utánzatát is. Csupán egy nehezen bizonyítható elképzelés él a szőlőhegy (latinul promontorium) terroir-ral való hasonításáról (BÁNYAI B. et al. 2012). A hasonítás már csak azért is sántít, mert az adott történelmi korban a terroir hazájában, a Francia Királyság területén sem beszéltek ilyen értelemben vett terroir-ról (LETURCQ, S. 2020). A Tokaji OEM-körzet néhány parcelláján kívül tehát inkább a dúlőket tekintjük a terroir letéteményesének, és ehhez elég csak elolvasni néhány borászat promóciós szövegét vagy éppen a Nagy magyar boratlasz fejezeteit.

De miért a dűlőt fogadjuk el terroir-ként? Ennek többféle oka van. Egyrészt szerepet játszik benne a szocializmus időszaka, amikor a tömegtermelés favorizálása miatt nem volt érdemes törődni az egyediségeket adó területekkel, így a szőlőrekonstrukció során ezekre oda sem figyelve telepítettek hatalmas, összefüggő szőlöültetvényeket. Másrészt a rendszerváltás után az új borvidéki rendszer létrehozása, majd az uniós eredetvédelem alkalmazása során sem mindig törekedtek a borvidékek ezeknek a lehetôségeknek a kiaknázására. Sőt, egyes kiemelkedő minőséget adó dűlők területét még meg is növelték, hiszen az adott néven eladható borok ára jóval magasabb lehet. Azt is mondhatnánk, hogy még csak most tanuljuk meg értékelni dűlőink adottságait és különbségeit, így kerülhetnek piacra néha szigorúan dúlószelektált borok.

Mint fentebb említettem, talán Tokaj az egyetlen borvidék, ahol valódi terroir-ról beszélhetünk. A borvidék szívének nevezhető Mádon a dúlőket több helyen is aldúlőkre bontották. Az egész ország legkiemelkedőbb dúlői közé tartozó Szent Tamáson belül helyezkedik el a Makovica- és a Fürdő-aldűlő; a Betseken belül pedig többek között a Nagy-Betsek, Kis-Betsek, és a Korposd. E területeken a talaj elképesztő változatosságú, a különböző vulkanikus események sokféle ásványi anyagot juttattak felszínre, amelyek 
meghatározzák az adott terroir-on készülő borok tulajdonságait. Ezeket a dúlőket emeli ki a tanulmányában Boros L. (2011). A cikk természetesen nem a terroir-ról szól, de mégis, ez a fogalom nagyon kevés hazai földrajzi megjelenésének egyike.

Tokaj mellett a Nagy-Somlói OEM-körzet termelői azok, akik leggyakrabban említik a terroir-t. Ennek oka, hogy a Somló olyan egyedi kőzettani adottságokkal bír, ami világszinten is ritkaság. A fogalom értelmezésének hazai korlátaira bizonyíték viszont az, hogy leggyakrabban az „egész Somló egy terroir” hozzáállást képviselik, ami már önmagában ellentmond annak, amit a terroir jelent. Holott az OEM-körzet eredetvédelmi szabályozásának átértelmezésével épp a Somlón lehetne karakteresen megjeleníteni a termőhelyi különbségeket: szinte az egyetlen termőhelyi körzetünk, ahol az összes égtáj felé néznek termőterületek - tehát igen hangsúlyosan lehetne jelezni a mezo- és mikroklimatikus különbségeket; az anyakőzet különböző típusai (kukoricabazalt, salakos bazalt), és azok eltéró tulajdonságai is sokkal területibb alapú megközelítést tennének lehetôvé például a legkiemelkedőbb adottságokkal bíró Arany-hegy-dűlő külön szabályozásával. És ha ezekhez a természeti adottságokhoz hozzátesszük a terület borászati, társadalmi hagyományait, sajátos borkészítési technológiáját, máris a terroir komplex megjelenését figyelhetjük meg.

A hazai borvidék-dúlő-terroir kérdés kidolgozatlanságához hasonlóan a hazai definiálás is gyerekcipőben jár. A fentebb már idézett OIV-definíciót több előadáson, konferencián hallani lehet, ugyanakkor a köznapi használatban csupán ködös elképzelés él a terroir-ról. Az errôl szóló hazai cikkek túlnyomó többsége nem lép át a természetföldrajzi megközelítésen. Első helyen szinte mindig az éghajlatot emelik ki: ilyenkor a mikroklíma kifejezést használják, noha a terroir esetében a mezoklíma a helyes meghatározás (LócZY D.-NyizsalovszKi R. 2005; NAgymarosy A. 2013). Hangsúlyos elem a terület fekvése (tengerszint feletti magasság, tájolás, lejtőszög) és a talaj állapota (fizikai és kémiai tulajdonságai). Ez utóbbinál az elmúlt évek terepkutatásai elsődleges fontosságúvá tették a vízelvezetô képességet (BÁLo B. et al. 2013), aminek nagy szerepe van a szőlő által felvett ásványi anyagok mennyiségében és minőségében - azaz a terroir megjelenésében a borkészítés során. Szintén az elmúlt évek mutattak rá arra, hogy a bor készítése során használt élesztőtörzsek is különböznek egymástól, területtől (terroir-tól) függően (NAGYMAROSY A. 2013). Ugyanakkor a felsorolás végén kerül csak sorra az emberi szerep, a humán hatás.

Az egyik legelismertebb magyar borszakértő, borszakíró, nemzetközi borakadémikus KIELMAYER K. (2010) a „4T” fogalmát használja terroir-ként: talaj (termőterület), természet (éghajlat tágabb értelemben, mikroklíma), történelem és társadalom Ugyanakkor ő is elismeri, hogy ezeket a T-ket lehet bővíteni tradícióval, technológiával, tőkével - tehát nem kiforrott definícióról van szó. A Nagy magyar boratlasz szerzői sem definiálnak, az „ezzel az idegen szóval fejezzük ki a termóhelyet, de abban az értelemben, hogy a talpunk alatt termó területet és a fejünk felett lévó égboltot a szó legtágabb értelmében beleveszszük" mondatot ugyanis nehéz meghatározásként értékelni (BÁNYAI, B. et al. 2012. 28.).

A hazai borászokat megkérdezve kijelenthetjük, hogy még akár OEM-körzeteken belül is más a terroir-ról alkotott elképzelésük. Az első helyen mindenki a természeti tényezőket említi, de jól láthatóan a termőhelytől megkülönböztethetően: a karakteres, jellegzetes anyakőzetű területek termelői a talajt emelik ki (Nagy-Somlói, Badacsonyi, Tokaji OEMkörzetek termelői), hiszen ők az ásványosság adta karaktert tekintik boraik fő vonzerejének; míg a többieknél sokkal inkább az éghajlat, a mikroklíma kerül előtérbe (Soproni, Móri, Villányi, Hajós-Bajai körzetek). Az is felismerhetó, hogy a társadalmi vonatkozások hangsúlyozása szintén inkább a második csoporthoz köthetô, bár ezek megfogalmazása általában kevésbé volt karakteres, és mindig csak a felsorolás végén jelentkeztek (,,ember”, „,hagyomány”, „helyi szakmai szokások”). 


\section{Összefoglalás}

A terroir értelmezése egy háromszögben képzelhető el: az egyik csúcsán a francia értelmezéssel, amely mára a terroir társadalmi vonásait helyezi előtérbe; a másik, ehhez viszonylag közel található csúcsán az alapvetően természeti megközelítésú, hagyományos terroir-felfogással, a harmadik, az előző kettőtől távol levő csúcsponttal, amely az újvilági, a terroir-t gyakorlatilag elutasító álláspontot képviseli. Ez utóbbi felfogás az újvilági bortermelés további felfutásával finomodni fog, el fogja veszíteni merev terroir-ellenességét.

A terroir jelenleg fóként természeti fogalomként él a borászatban és köztudatban is. Ennek az az oka, hogy a természeti tényezők sokkal előnyösebben használhatók az adott terroir bemutatására, ezáltal közérthetőbb, megoszthatóbb. Ennek ellenére látható, hogy a terroir fogalma egyre jobban bővül, mára kiegészült a társadalmi szempontok egyre erósebb hangsúlyozásával. Az egyre letisztultabb területi megközelítés a társadalmi folyamatok felértékelődéséhez fog vezetni. Egy terület létezhet hozzá kapcsolódó termék nélkül, de a terroir egy bizonyos termék területe, amelyhez társadalmi-technológiai megközelítés is szükséges. Végeredményben a terroir fogalmának bővülése megállíthatatlan lesz.

Ugyanúgy Magyarországon is szükség van arra, hogy a terroir fogalmát pontosabban értelmezzük. Ehhez az kell, hogy mind a magyar borászati szakma, mind a szőlészet-borászat tudományág megpróbálja kidolgozni a XXI. századi viszonyokra alkalmazható fogalmat. Amíg ugyanis a borászok körében nem alakul ki az egységes, borvidékekre, borrégiókra kiterjedő terroir-értékelés, addig tulajdonképpen gyakorlati jelentősége nincs is a kérdésnek. Ugyanakkor érdemes lenne néhány borvidéken kísérleti jelleggel megpróbálkozni a terroir jellegú klasszifikáció kialakításával (elsőként, mondjuk, a Tokaji borvidék területén), és nem csak az OEM eredetvédelmi leírások technológiai korlátozásaival szabályozni a borkészítést. Ki lehetne használni azt, hogy a terroir nem csak területi dimenzió, hanem identitás, gyakorlatilag megfoghatatlan kulturális erőforrás. Nyugati - elsősorban francia - példákon láthatjuk, hogy a terroir a nemzeti borkultúra pillérévé vált, emellett az AOC-rendszer a regionális fejlódés eszköze lett (DEMossier, M. 2011). Ezt kellene a megfelelő társadalmi és szakmai vita után beépíteni a hazai borágazatba. Más kérdés, hogy kis területű, homogénebb felépítésû borvidékeinken milyen lehetőség lenne erre.

Itt lenne nagy szerepe a földrajznak. Mint szintetizáló tudomány, képesnek kell lennie megteremteni a maga terroir definícióját, hiszen mára gyakorlatilag megkerülhetetlen fogalomról beszélünk. A földrajzi, térbeli lehatárolás növelni képes a termelékenységet, hiszen egy ilyen esetben van követendő gazdasági példa, közös elv, majd ezeken kialakuló társadalmi bizalom. A természetföldrajz mellett a társadalomföldrajznak ebben nagyon fontos szerepe kell legyen, kutatni kell a terroir-ként lehatárolt terek homogén társadalmigazdasági folyamatait. Véleményem szerint ugyanis a terroir tipikus földrajzi fogalom, amely az agrártáj meghatározott, szőlőmúvelésre használt területét fedi le, s ahol a természeti környezet és a történelmi-kulturális tradíciók egyedi borászati terméket hoznak létre.

\section{Köszönetnyilvánítás}

Köszönetemet fejezem ki a tanulmány megírásához segítséget nyújtó, a Soproni, Pannonhalmi, Nagy-Somlói, Badacsonyi, Móri, Villányi, Hajós-Bajai és Tokaji OEM-körzetekben dolgozó borász kollégáknak. 


\author{
KiSMARJAi BALÁZS \\ ELTE TTK Földtudományi Doktori Iskola, Budapest \\ balazs.kismarjai@gmail.com
}

\title{
IRODALOM
}

Atkinson, J. 2011: Terroir and the Côte de Nuits. - Journal of Wine Research 22. 1. pp. 35-41.

Bálo B.-Tóth E.-Olasz A.-Katona Z.-Simon Z.-Burai P.-Bisztray Z. 2013: A terroir kutatás új irányai hazánkban, szemelvények a világból. - Őstermelő 2013. 5. pp. 62-68.

BÁnyai B.-ERcsey D.-MÉszárois G.-Tompa I. 2012: Nagy magyar boratlasz. - Mountner \& Pitman KFT.

Barjolle, D.-Boisseaux, S.-Dufour, M. 1998: Le lien au terroir. - Institut d'economie rurale, ETHZ. Antenne Romande 1998.

BoRos L. 2011: Tokaj-Hegyalja szőlőterületének idő- és térbeli változásai a 18-20. század folyamán. - Földrajzi Közlemények 135. 4. pp. 445-457.

Casabianca, F.-Giraud, G. 2011: Terroir et typicité: un enjeu de terminologie pour les Indications Géographiques. Vie Congres international sur les terroirs viticoles, Bordeaux-Montpellier, 2-8 juillet 2006.

Charters, S. 2010: Marketing terroir: A conceptual approach. - 5th International Academy of Wine Business Research Conference, 8-10. Feb. 2010, Auckland.COCHET, H. et al. 2006: Fonctionnement et performances économiques des systémes de production agricole: une démarche á l'échelle régionale. - Cahiers Agricultures 15. 6.

Cochet, H. 2012: The systeme agraire concept in franchophone peasant studies. - Geoforum 43. pp. $128-136$.

Cross, R.-Plantinga, A.J.-Stavins, R.N. 2011: What is the Value of Terroir? - American Economic Review, 101. 3. pp. 152-156.

CSATÁRi B. 2006: A megélt tér élménye: gondolatok a táj, a terület- és a vidékfejlesztés kapcsolatáról. - Falu város régió, 2006. 3. pp. 23-25.

Deloire, A.-Prévost, P.-Kelly, M. 2008: Unravelling the Terroir Mystique - an agro-socio-economic perspective. - Perspectives in Agriculture, Veterinary Science, Nutrition and Natural Resources. 32.3. pp. 1-9.

Demossier, M. 2011: Beyond terroir: territorial construction, hegemonic discourses, and French wine culture. - Journal of the Royal Anthropological Institute 17. pp. 685-705.

DÉKÁNY T. 2017: A terroir és ami mögötte van. - Borászati Füzetek 2017.06.27. pp. 20-22.

Dougherty, P. H. 2012: Introduction to the Geographycal Study of Viticulture and Wine Production. - In: DougherTy, P. H. (szerk.): The Geography of Wine. Regions, Terroir and Techniques. Springer. pp. 3-36.

ENyEDI Gy. 1965: A Föld mezőgazdasága (Agrárföldrajzi tanulmány). - Mezőgazdasági Kiadó, Budapest.

Haynes, S. J. 1999: Geology and Wine 1. Concept of Terroir and the Role of Geology. - Geoscience Canada 26. 4. pp. 190-194.

ILLÉs I. 2008: Regionális gazdaságtan - Területfejlesztés. TYPOTEX Kiadó, Budapest.

Imre, S. P.-Mauk, J. L. 2009: Geology and Wine 12. New Zealand terroir. - Geoscience Canada 36. 4. pp. $145-159$.

JeKEL, B. 1982: California wines: the quality factors. - Decanter 7. 12. pp. 67-68.

JEKEL, B. 1983a: Soil and the taste of wine. - Decanter 8. 5. 59 p.

JEKEL, B. 1983b: Soil and wine - the debat continues. - Decanter 8. 10. 15 p.

Johnson, H.-Robinson, J. 2012: The World Atlas of Wine. - Mitchell Beazley, London.

Jones, G. V.-SneAD, N.-Nelson, P. 2004: Geology and Wine 8. Modelling Viticultural Landscapes: A GIS Analysis of the Terroir Potential in the Umpqua Valley of Oregon. - Geoscience Canada 31. 4. pp. 167-178.

KARÁCSONYI D. 2010: Ukrajna vidékföldrajza. - Trefort Kiadó, Budapest.

Lemaire, D.-Kasserman, D. 2012: Bordeaux and Burgundy: A Comparison of Two French Regions in Transition. - In: Dougherty, P. H. (szerk.): The Geography of Wine. Regions, Terroir and Techniques. Springer.

LeturcQ, S. 2020: Le terroir, un concept anhistorique. - In: YenQué, J-L.-STengel, K. (szerk.): Le terroir viticole. Espaces et figures de la qualité. Presses universitaires Francois-Rabelais

LócZy D.-NyıZSALOVSZKi R. 2005: Borvidékeink földhasználati változásainak tájökológiai értékelése. - Tájökológiai Lapok 3. 1. pp. 1-12.

Maby, J. 2002: Paysage et imaginaire: l'exploitation de nouvelles valeurs ajoutées dans les terroirs viticoles. Annales de Géographie 624. pp. 198-211.

Nagymarosy A. 2013: Bor és Terroir. - Bor és Piac 13.9-10. pp. 14-17.

Nemzeti Agrárprogram 1997: Agrárprogram Szakmai Füzetek 13. - Vidékfejlesztés. Földmúvelésügyi Minisztérium, Budapest.

PitTe, J-R. 1999: Á propos du terroir. Annales de Géographie 605. pp. 86-89.

PitTE, J-R. 2008: Bordeaux/Burgundy. A Vintage Rivalry. - University of California Press. 
Polge, M. 2003: Petite entreprise et stratégie de terroir. Revue française de gestion 144. pp. 181-193.

Prats, B. 1983: The terroir is important. - Decanter 8. 7. 16 p.

Prévost, P.-Capitaine, M.-Gautier-Pelissier, F.-Michelin, Y.-Jeanneaux, P.-Fort, F.-Javelle, A. - Moïti-Maïzi, P.-Lériche, F.-Brunschwig, G.-Fournier, S.-Lapeyronie, P.-Josien, É. 2014: Le terroir, un concept pour l'action dans le développement des territoires. VertigO - la revue électronique en sciences de l'environnement 14. 1.

Shanmuganathan, S. 2010: Viticultural Zoning for the Identification and Characterisation of New Zealand „Terroirs” Using Cartographic Data. - GeoCart'2010 and ICA Symposium on Cartography. New Zealand Cartographic Society Inc, 2010.

Sommers, B. J. 2008: The Geography of Wine. How Landscapes, Cultures, Terroir, and the Weather Make a Good Drop. - Penguin Group

SPIELMANN, N.-GÉLINAS-CheBAT, C. 2012: Terroir? That's not how I would describe it. - International Journal of Wine Business Research 24. 4. pp. 254-270.

Szabó Sz. 2011: Vidéki térségek Magyarországon, és azok főbb társadalmi-gazdasági problémái. In: SzABó Sz. (szerk.): Vidéki térségek Magyarországon. Trefort Kiadó pp. 11-64.

Trubek, A. B. 2008: The Taste of Place. A Cultural Journey into Terroir. - University of California Press.

Unwin, T. 1991: Wine and the Vine. An Historical Geography of Viticulture and the Wine Trade. - Routlidge.

Unwin, T. 2012: Terroir: At the Heart of Geography. In: Dougherty, P. H. (szerk.): The Geography of Wine. Regions, Terroir and Techniques. Springer. pp. 37-48.

VAn Leeuwen, C.-Seguin, G. 2006: The Concept of Terroir in Viticulture. - Journal of Wine Research 17. 1. pp. $1-10$.

WiLson, J. E. 2001: Geology and Wine 4. The Origin and Odyssey of Terroir. - Geoscience Canada 28. 3.

\section{Internetes oldalak}

KIELMAYER K. (2010): http://www.boraszportal.hu/hirszuret/terroir_valosag_vagy_marketing_fogas-1451

Nemzeti Vidékstratégia 2012-2020:

http://videkstrategia.kormany.hu/download/4/37/30000/ /Nemzeti\%20Vidékstratégia.pdf

OIV 2010: http://www.oiv.int/public/medias/379/viti-2010-1-en.pdf

UNESCO 2005: http://unesdoc.unesco.org/images/0015/001543/154388f.pdf 